\title{
Coated Vesicle
}

National Cancer Institute

\section{Source}

National Cancer Institute. Coated Vesicle. NCI Thesaurus. Code C32331.

A cytoplasmic vesicle that is coated with proteins which stabilize its structure and facilitate targeting. 